\title{
Comparative growth response related to hair mineral analysis in dromedary camel calves
}

\author{
Asim Faraz ${ }^{*}$, Abdul Waheed ${ }^{1}$, Ayman Balla Mustafa ${ }^{2}$, Nasir Ali Tauqir ${ }^{3}$ and Ahmed Omar Eldeib ${ }^{4}$ \\ ${ }^{1}$ Department of Livestock and Poultry Production, Bahauddin Zakariya University Multan, Multan, Pakistan \\ ${ }^{2}$ Therapeutic Nutrition Department, Faculty of Nursing and Health Sciences, Misurata University, Misurata, Libya \\ ${ }^{3}$ Department of Animal Science, University of Sargodha, Sargodha, Pakistan \\ ${ }^{4}$ Faculty of Veterinary Medicine, Misurata University, Misurata, Libya
}

\begin{abstract}
Background: The dromedary camel plays a significant role in supporting the livelihood of pastoral and agropastoral systems, as well as a source of income for the national economy in arid regions.

Aim: The current study was executed to check the comparative growth response in relation to hair mineral status in Marecha camel calves reared under an intensive management system and an extensive management system in Thal desert Punjab, Pakistan.

Methods: Twelve male and female Camelus dromedarius calves of almost the same weight and age were divided into two groups of 6 each ( 3 male and 3 female). The calves of the first group were maintained at the Camel Breeding and Research Station, Rakh Mahni, in a semi-open housing system, while the second group was maintained in available housing under field conditions. Calves in the first group were fed concentrate at the rate of $1 \mathrm{~kg} / \mathrm{head} / \mathrm{day}$ along with gram straw (Cicer arientinum) ad libitum, while calves in the second group were allowed to graze/browse for 10 hours daily along with household refusals, including kitchen wastes. Water was provided twice a day. Impressum's digital weighing scale was used for fortnightly weighing. Data collected on different parameters were subjected to statistical analysis with $2 \times 2$ factorial arrangements of treatments under a completely randomized design.

Results: After the 120-day trial period, the mean body weight and average daily gain of male and female calves were significantly increased $(p<0.05)$ in IMS as $80.8 \pm 2.7,77.8 \pm 2.7 \mathrm{~kg}$ and $0.67 \pm 0.02,0.65 \pm 0.02 \mathrm{~kg} / \mathrm{days}$ than EMS as $64.5 \pm 2.6,52.9 \pm 2.6 \mathrm{~kg}$ and $0.54 \pm 0.02,0.44 \pm 0.02 \mathrm{~kg} /$ days. Intake of crop residues $(p<0.05)$ was found to be $6.9 \pm 0.45$ and $6.4 \pm 0.45 \mathrm{~kg} /$ days for male and female calves in IMS, respectively, and $3.5 \pm 0.23$ for male and female calves in EMS, respectively. The conversion index $\mathrm{g} / \mathrm{kg}$ average daily intake was 97.1, 101.5 and 154.3, 125.7 for male and female calves in IMS and EMS, respectively. Regarding hair mineral status, $\mathrm{Ca}, \mathrm{Mg}, \mathrm{Cu}, \mathrm{Zn}, \mathrm{Fe}$, and $\mathrm{Mn}$ concentrations were found to be significantly different $(p<0.05)$ among calf groups in IMS and EMS.

Conclusion: This study indicates that wool analysis and management of weight gain in camel calves should be further explored to support increased meat supply in arid regions.
\end{abstract}

Keywords: Camel, Growth, Management, System, Wool.

\section{Introduction}

Food security is a challenging issue in the current days for developing countries due to the rapid increase of growth and limited resources, and exploration of new resources is the need of the hour. In this context, the indigenous sources are of keen interest. The camel is the future hope in this regard (Faraz et al., 2019a), which is an important source of food subsistence and income for pastorals, arid, and semiarid people (Faye, 2016). A camel can survive and produce in severe, hot, and hostile environments with equally good potential as other domestic animals in favorable environments. It is the best food source for dry areas, which nourishes the Bedouins, nomads, and pastoralists since centuries (Faraz, 2020a). Dromedary camel is one of the most important domestic animals in desert regions, as it is equipped to produce milk, meat, and wool at comparatively low costs and in extremely harsh conditions (Mustafa et al., 2015).

A camel can utilize poor quality forages with much more efficiency, as it retains fiber in its fore stomach for as long as 70 hours (Von Engelhardt et al., 2006). It reutilizes urea for microbial protein synthesis and can use water economically for almost all metabolic functions. With 1.1 million heads (FAOSTAT, 2019; GOP, 2019-20), the camel population in Pakistan is enough to contribute to food security in the national economy and for diverse ecozones.

However, for contributing to this, improvement of meat productivity in the camel herd is necessary. One way could be more intensive feeding to increase the growth of young camels. Mineral estimation in camel hair is a relatively newer concept in Pakistan. It could be an interesting tool for monitoring the general 
health status of camel calves (Faraz et al., 2019b). However, in Pakistan, camel hairs have not been taken up for mineral estimation so far. Hence, this study was planned to evaluate the growth potential related to hair mineral status in Marecha camel calves under an intensive management system (IMS) and an extensive management system (EMS) in its natural habitat.

\section{Materials and Methods}

\section{Study area and meteorological conditions}

This study was conducted at the Camel Breeding and Research Station (CBRS), Rakh Mahni, Tahsil Mankera, District Bhakkar. The CBRS is located in Thal area between $31^{\circ} 10^{\prime}$ and $32^{\circ} 22^{\prime}$ north latitude and $70^{\circ} 47^{\prime}$ and $72^{\circ}$ east longitude. Most of the area lies in the desert plain of Thal. This area is included in the agro-ecological zone-III A and B (sandy desert area), having narrow strips of sand ridges and dunes. The climate is arid to semiarid, subtropical, and continental and the mean monthly highest temperature goes up to $45.6^{\circ} \mathrm{C}$, while in winter it goes from $5.5^{\circ} \mathrm{C}$ to $1.3^{\circ} \mathrm{C}$. The mean annual rainfall in the region ranges from 150 to $350 \mathrm{~mm}$, increasing from south to north (Rahim et al., 2011).

\section{Animal management}

Marecha camel calves were maintained at the CBRS, Rakh Mahni, Tahsil Mankera, District Bhakkar, and the nearby field was used for this experiment to compare the efficiency of body weight gain and hair mineral status in camel calves raised under an IMS and an EMS. Twelve Marecha calves (Camelus dromedarius) aged around $330 \pm 30$ days and having group weight of 1350 and $1340 \mathrm{~kg}$, respectively, were used in the 120-day trial, with additional 15 days adaptation period. Of these, six (three male and three female) belonged to the CBRS and were reared under IMS and the other six calves (three male and three female) were owned by private farmers and reared under EMS. The experiment was conducted during the months of March to August 2014. Before the start of the experiment, all the camel calves were marked for identification and dewormed to reduce the parasitic load. Calves were housed in semi-open pens throughout the trial at a farm in IMS and under available housing in EMS. Initial body weights of the camel calves were recorded before shifting these calves to the respective treatment groups, and thereafter all the experimental calves were weighed fortnightly on a digital weighing scale (Impressum, Pakistan) before morning feeding.

\section{Experimental feeding plan}

Water was provided twice a day in both the systems. The animals in the first group were fed concentrate at the rate of $1 \mathrm{~kg} / \mathrm{head} /$ day along with gram straw (Cicer arientinum) ad libitum in IMS. While in EMS, the calves were allowed to graze/browse for 10 hours (as per prevailing practice) along with feeding of households (kitchen waste, house refusals, and some grains). The ingredients and the chemical composition of the experimental ration are given in Table 1, while the compositions of gram straw and different grazing/ browsing species are given in Table 2 .

\section{Data collection}

Daily growth rate average daily gain (ADG) was calculated by fortnightly weighing as follows: Current weight-previous weight $/ 15$. The feed intake of crop residues was calculated as the difference between the residual amount of feed and the amount offered. The average dry matter values of feed were measured and the dry matter intake (DMI) was then determined.

\section{Laboratory analysis}

The concentrate, crop residues, and herbage samples of the grazing/browsing material were analyzed for percent dry matter, crude protein, crude fiber, ether extract, and ash (AOAC, 1990). Neutral detergent fiber (NDF) and acid detergent fiber (ADF) were also determined (Van Soest et al., 1991).

\section{Hair collection, digestion, and analyses}

Hair samples were collected from shoulder, neck, hump, and mid region of the body of camel calves. The hair was cut with stainless steel scissors into pieces of about $1 \mathrm{~cm}$ length from each region and mixed well to ensure homogeneity. The skirting of the sample was carried out properly. Samples were washed with acetone and were filtered and rinsed with plenty of water. They were dried in a hot air oven and $0.5 \mathrm{~g}$ of dried mass was taken for further processing. Digestion of hair samples was carried out at the Animal Nutrition Lab, Faculty of Animal Husbandry, University of Agriculture Faisalabad. Concentrated nitric acid $(2 \mathrm{ml})$ was added to each hair sample and was kept at $100^{\circ} \mathrm{C}$ until half of the total volume evaporated. The samples were taken out and cooled. Concentrated perchloric acid $(2 \mathrm{ml})$ was added and again the sample was kept until half of the total volume evaporated. After this procedure, distilled water was added to give a total volume of 10 $\mathrm{ml}$ (Bhakat et al., 2009). The solution was used for

Table 1. Ingredients of experimental ration and chemical composition of experimental ration.

\begin{tabular}{lccc}
\hline Ingredients (\%) & Ration & Parameters (\%) & Ration \\
\hline Maize grain & 9 & DM & 90.32 \\
Wheat bran & 24 & CP & 18.06 \\
Cottonseed cake & 25 & NDF & 29.09 \\
Rapeseed cake & 6 & ADF & 14.41 \\
Corn gluten (30\%) & 20 & TDN & 70 \\
Molasses & 14 & ME & 2.41 \\
DCP & 1 & & \\
Salt & 1 & & \\
\hline
\end{tabular}

$\mathrm{DM}=$ Dry matter; $\mathrm{CP}=$ Crude protein $; \mathrm{NDF}=$ Neutral detergent fiber; $\mathrm{ADF}=$ Acid detergent fiber; $\mathrm{TDN}=$ Total digestible nutrients; $\mathrm{ME}=$ Metabolizable energy.

Adapted from Faraz et al. (2018). 
the determination of important macrominerals and microminerals. The concentrations of macrominerals ( $\mathrm{Ca}$ and $\mathrm{Mg}$ ) and microminerals $(\mathrm{Cu}, \mathrm{Fe}, \mathrm{Mn}$, and $\mathrm{Zn})$ were determined by the atomic absorption spectrophotometer (Method 965.09A; AOAC, 1990) at the Hi-Tech Lab, University of Agriculture Faisalabad. Statistical analysis

Data collected on different parameters were analyzed statistically by using Fisher's analysis of variance technique having $2 \times 2$ factorial arrangements of treatments under completely randomized design (CRD) (Steel et al., 1997) using generalized linear model (GLM) of Statistical Package for the Social Sciences software (SPSS, 2008). Tukey's test at 0.05 levels of significance was used to compare the differences among the treatment means.

\section{Ethical approval}

In the current study, camels were fed according to the farm routine practices having grazing/browsing and stall feeding available. They were provided fresh, clean water and salt loops. Camels were vaccinated and dewormed according to scientific recommendations. All institutional and national guidelines for the care and use of experimental animals were followed (ethical committee approval number: DGS No/19457-62).

\section{Results}

Calves of almost similar weights were selected in both management systems for this study. After the 120-day trial period, the overall weight gain and daily weight gain (DWG) (growth rate) were $80.8 \pm 2.7,77.8 \pm 2.7$ $\mathrm{kg}$ and $670,650 \mathrm{~g} /$ days for male and female calves in IMS, respectively, and $64.5 \pm 2.6,52.9 \pm 2.6 \mathrm{~kg}$ and $540,440 \mathrm{~g} /$ days for male and female calves in EMS, respectively (Table 3 ).

The daily feed intake (DFI) of crop residues was found to vary significantly $(p<0.05)$ among calf groups

Table 2. Proximate analysis (\%) of crop residue and different grazing/browsing species.

\begin{tabular}{|c|c|c|c|c|c|c|c|}
\hline Feed/Forage Species & DM & $\mathbf{C P}$ & $\mathbf{E E}$ & CF & NDF & ADF & Crude Ash \\
\hline Gram straw (Cicer arietinum) & 93.53 & 9.72 & 2.60 & 44.4 & 68.7 & 47.6 & 7.83 \\
\hline Kikar (Acacia nilotica) & 28.5 & 16.71 & 1.79 & 25.08 & 55.4 & 25.4 & 5.94 \\
\hline Phulai (Acacia modesta) & 53.4 & 13.23 & 2.21 & 35.40 & 46.6 & 28.78 & 6.94 \\
\hline Beri leaves (Ziziphus mauritiana) & 40.2 & 15.52 & 5.77 & 28.02 & 48.3 & 26.9 & 8.48 \\
\hline Siras (Albizia lebbeck) & 37.3 & 16.17 & 6.58 & 27.25 & 43 & 29 & 16.33 \\
\hline Jand (Prosopis cineraria) & 46.15 & 16.86 & 6.52 & 19.14 & 47.5 & 29 & 4.95 \\
\hline Khagal (Tamarix aphylla) & 31.9 & 12.81 & 3.25 & 17.32 & 42.4 & 31.6 & 13.03 \\
\hline Dhaman (Cenchrus ciliaris) & 31.9 & 14.69 & 3.94 & 26.51 & 38.53 & 18.15 & 15.71 \\
\hline Persain (Suaeda fruticosa) & 30.3 & 10.57 & 5.52 & 33.14 & 48.7 & 27.6 & 7.54 \\
\hline Khawi (Cymbopogon schoenanthus) & 34.6 & 9.53 & 2.01 & 35.67 & 62.1 & 43.5 & 7.14 \\
\hline Kali bui (Kochia indica) & 33.78 & 10.80 & 4.91 & 27.61 & 58.6 & 39.76 & 13.32 \\
\hline Bhakra (Tribulus terrestris) & 32.1 & 8.76 & 4.58 & 32.63 & 46.7 & 35.4 & 9.64 \\
\hline Kari (Capparis spinosa) & 36.7 & 17.84 & 1.18 & 30.75 & 51.8 & 33.5 & 6.97 \\
\hline Laana (Haloxylon salincornicum) & 34.2 & 15.85 & 3.09 & 32.33 & 51.34 & 37.5 & 11.93 \\
\hline Phog (Calligonum polygonoides) & 34.7 & 8.95 & 4.82 & 23.42 & 49.6 & 31.9 & 8.76 \\
\hline Karir (Capparis decidua) & 49.4 & 16.75 & 1.52 & 24.64 & 53.6 & 37.8 & 14.76 \\
\hline Khar laana (Haloxylon recurvum) & 47.9 & 12.36 & 3.32 & 24.95 & 49.2 & 31.3 & 12.15 \\
\hline
\end{tabular}

$\mathrm{DM}=$ Dry matter; $\mathrm{CP}=$ Crude protein $\mathrm{EE}=$ Ether extract; $\mathrm{CF}=$ Crude fiber; $\mathrm{NDF}=$ Neutral detergent fiber; $\mathrm{ADF}=$ Acid detergent fiber. Adapted from Faraz et al. (2018).

Table 3. Overall weight gain $(\mathrm{kg})$ and growth rate $(\mathrm{kg} /$ day) of male and female camel calves in IMS and EMS.

\begin{tabular}{lcccc}
\hline \multirow{2}{*}{ Parameter } & \multicolumn{2}{c}{ IMS } & EMS \\
\cline { 2 - 5 } & Male $(\boldsymbol{n}=\mathbf{3})$ & Female $(\boldsymbol{n}=\mathbf{3})$ & $17.7 \pm 1.0^{\text {ax }}$ & Female $(\boldsymbol{n}=\mathbf{3})$ \\
\hline Growth at 30 days & $21.7 \pm 0.9^{\text {ax }}$ & $20.3 \pm 0.9^{\text {ay }}$ & $14.6 \pm 1.0^{\text {by }}$ \\
Growth at 60 days & $20.2 \pm 0.6^{\text {ax }}$ & $19.7 \pm 0.6^{\text {ay }}$ & $16.4 \pm 0.8^{\text {ax }}$ & $14.3 \pm 0.8^{\text {by }}$ \\
Growth at 90 days & $19.7 \pm 0.7^{\text {ax }}$ & $19.2 \pm 0.7^{\text {ay }}$ & $15.4 \pm 0.7^{\text {ax }}$ & $12.5 \pm 0.7^{\text {by }}$ \\
Growth at 120 days & $19.3 \pm 0.6^{\text {ax }}$ & $18.7 \pm 0.6^{\text {ay }}$ & $64.5 \pm 2.6^{\text {ax }}$ & $52.9 \pm 2.6^{\text {by }}$ \\
Overall weight gain & $80.8 \pm 2.7^{\text {ax }}$ & $77.8 \pm 2.7^{\text {ay }}$ & $0.54 \pm 0.02^{\text {ax }}$ & $0.44 \pm 0.02^{\text {by }}$ \\
DWG & $0.67 \pm 0.02^{\text {ax }}$ & $0.65 \pm 0.02^{\text {ay }}$ & & $11.5 \pm 0.6^{\text {by }}$ \\
\hline
\end{tabular}

Means having different superscripts in columns are significantly different $(p<0.05)$.

IMS = Intensive management system; EMS = Extensive management system.

Adapted from Faraz et al. (2017, 2018). 
between IMS and EMS, with IMS being higher than EMS. The intake of crop residues was found to be $6.9 \pm$ 0.45 and $6.4 \pm 0.45 \mathrm{~kg} /$ days in male and female calves in IMS, respectively, and $3.5 \pm 0.23$ for male and female calves in EMS, respectively. The weight gain for $1 \mathrm{~kg}$ intake of crop residues in the conversion index is 97.1 and $101.5 \mathrm{~g} / \mathrm{kg}$ average daily intake (ADI) for males and females in IMS, respectively, and 154.3 and 125.7 $\mathrm{g} / \mathrm{kg}$ ADI for males and females in EMS, respectively (Table 4).

The mean values of macro $(\mathrm{Ca}$ and $\mathrm{Mg})$ and trace elements $(\mathrm{Cu}, \mathrm{Zn}, \mathrm{Fe}$, and $\mathrm{Mn})$ of male and female camel calves in the different farming systems were found to be significantly different $(p<0.05)$ for calcium, magnesium, copper, zinc, iron, and manganese between male and female calves, the values being higher in males than females in both systems (Table 5).

\section{Sex effect on growth}

\section{Discussion}

In the present study, male calves attained higher weights in both the systems, which may be due to the reason that more receptors are present on muscle cells for androgens that accelerate the growth (Hossner, 2005).
The highest growth of young males is a common feature in most of the farm animals and is widely reported in the literature. In camels, for example, similar observations were realized in Pakistan by Knoess (1977) and Qureshi (1986), who reported the average DWG as 1,400 $\mathrm{g}$ in male and $950 \mathrm{~g}$ in female camel calves and 1,500 $\mathrm{g}$ in male and $1,000 \mathrm{~g}$ in female camel calves, respectively. Ouda et al. (1992) studied the production performance of Somali and Rendille camels in northern Kenya and observed that sex and year significantly affect growth after 2 years of age. Kurtu (2004) reported that mature male calves were heavier than female calves by $38 \%$ in Ethiopia. Reported weight gain in calves was $411 \mathrm{~g} /$ days in males and $380 \mathrm{~g} /$ days in females, while weight gain after sexual maturity was $120 \mathrm{~g} /$ days in males and $60 \mathrm{~g} /$ days in females in northern Kenya (Musavaya, 2003).

Sahani et al. (1998) in India reported the ADG in 0-3 $(630,580 \mathrm{~g})$; 3-6 (640, 620 g); 6-9 (370, $390 \mathrm{~g})$; 9-12 (230, $230 \mathrm{~g})$; 18-24 (160, $200 \mathrm{~g}) ; 24-30$ (160, $170 \mathrm{~g})$, and 30-36 months $(180,140 \mathrm{~g})$ in male and female calves, respectively. Khanna et al. (2004) reported the $\mathrm{ADG}$ as 700 and $770 \mathrm{~g}$ in Jaisalmeri and Bikaneri Indian camel breeds from birth to 3 months of age, respectively.

Table 4. Average male and female camel calves' intake of crop residues (kg) and conversion index (g/kg ADI) on DM basis in IMS and EMS.

\begin{tabular}{lcccc}
\hline \multirow{2}{*}{ Parameter } & \multicolumn{2}{c}{ IMS } & EMS \\
\cline { 2 - 5 } & Male $(\boldsymbol{n}=\mathbf{3})$ & Female $(\boldsymbol{n}=\mathbf{3})$ & Male $(\boldsymbol{n}=\mathbf{3})$ & Female $(\boldsymbol{n}=\mathbf{3})$ \\
\hline ADI in 30 d & $6.5 \pm 0.44^{\text {ax }}$ & $5.9 \pm 0.44^{\text {ay }}$ & $3.3 \pm 0.22^{\text {bx }}$ & $3.3 \pm 0.22^{\text {by }}$ \\
ADI in 60 d & $6.9 \pm 0.45^{\text {ax }}$ & $6.4 \pm 0.45^{\text {ay }}$ & $3.5 \pm 0.23^{\text {bx }}$ & $3.6 \pm 0.23^{\text {by }}$ \\
ADI in 90 d & $7.5 \pm 0.46^{\text {ax }}$ & $6.8 \pm 0.46^{\text {ay }}$ & $3.8 \pm 0.24^{\text {bx }}$ & $3.8 \pm 0.24^{\text {by }}$ \\
ADI in 120 d & $7.9 \pm 0.45^{\text {ax }}$ & $7.4 \pm 0.45^{\text {ay }}$ & $4.0 \pm 0.25^{\text {bx }}$ & $4.0 \pm 0.25^{\text {by }}$ \\
DFI/animal & $6.9 \pm 0.45^{\text {ax }}$ & $6.4 \pm 0.45^{\text {ay }}$ & $3.5 \pm 0.23^{\text {bx }}$ & $3.5 \pm 0.23^{\text {by }}$ \\
Conversion index & 97.1 & 101.5 & 154.3 & 125.7 \\
\hline
\end{tabular}

Means having different superscripts in columns are significantly different $(p<0.05)$.

$\mathrm{ADI}=$ Average daily intake; IMS = Intensive management system; EMS = Extensive management system.

Adapted from Faraz et al. $(2017,2018)$.

Table 5. Wool mineral analyses of male and female camel calves in IMS and EMS.

\begin{tabular}{lcccc}
\hline \multirow{2}{*}{ Parameter $(\mathrm{mg} / \mathrm{dl})$} & \multicolumn{2}{c}{ IMS } & \multicolumn{2}{c}{ EMS } \\
\cline { 2 - 5 } & Male $(\boldsymbol{n}=\mathbf{3})$ & Female $(\boldsymbol{n}=\mathbf{3})$ & $\boldsymbol{n}=\mathbf{3})$ & Female $(\boldsymbol{n}=\mathbf{3})$ \\
\hline Calcium & $685.0 \pm 25.3^{\text {ax }}$ & $595.7 \pm 38.0^{\text {ay }}$ & $529.8 \pm 15.9^{\text {bx }}$ & $498.7 \pm 23.2^{\text {by }}$ \\
Magnesium & $104.3 \pm 2.0^{\text {ax }}$ & $101.2 \pm 0.9^{\text {ay }}$ & $87.8 \pm 3.4^{\text {bx }}$ & $83.5 \pm 4.0^{\text {by }}$ \\
Copper & $7.0 \pm 0.4^{\text {ax }}$ & $6.7 \pm 0.4^{\text {ay }}$ & $5.7 \pm 0.4^{\text {bx }}$ & $4.5 \pm 0.1^{\text {by }}$ \\
Zinc & $65.3 \pm 2.9^{\text {ax }}$ & $59.3 \pm 3.0^{\text {ay }}$ & $59.3 \pm 2.4^{\text {bx }}$ & $46.9 \pm 1.8^{\text {by }}$ \\
Iron & $322.2 \pm 6.3^{\text {ax }}$ & $311.1 \pm 6.3^{\text {ay }}$ & $300.6 \pm 3.1^{\text {bx }}$ & $242.3 \pm 4.7^{\text {by }}$ \\
Manganese & $46.5 \pm 1.7^{\text {ax }}$ & $40.7 \pm 0.3^{\text {ay }}$ & $32.5 \pm 2.4^{\text {bx }}$ & $27.0 \pm 1.6^{\text {by }}$ \\
\hline
\end{tabular}

Means having different superscripts in columns are significantly different $(p<0.05)$.

IMS = Intensive management system; EMS = Extensive management system. 
However, no significant difference was found between male and female calves regarding their DWG. Bakheit et al. (2012) studied the effect of management systems on growth rate of calves in North Kordofan, Sudan, and found no significant difference between male and female calves regarding their DWG. Faraz et al. (2017, $2018,2019 b)$ compared the growth performance of camel calves in different management systems and found higher weight gain in male calves than female calves.

\section{Diet effect on growth}

The ADGs significantly varied between groups, with IMS being higher than EMS. These findings are in line with that of Bhakat et al. (2008), who studied the effect of management systems on growth performance of dromedary camel calves in India. They used 10 camel calves aged between 7 and 10 months in their study and divided them randomly into two comparable groups of five each. The average initial body weight of both groups was almost similar. The groups were of hetero breed and sex combinations, each group contained three Jaisalmeri, one Bikaneri, and one Katchi breed, and four males and one female. At the end of the trial, the average total gain was almost double in the IMS than the semi-intensive management system (SIMS) group. The average growth rate was significantly higher in IMS (611 g/days) than SIMS.

Contrary to our observations, Bhakat et al. (2009) reported that the ADG (g/day) differed significantly among two systems, with SIMS being higher (325 and $476 \mathrm{~g} /$ days) than IMS (278 and $331 \mathrm{~g}$ /days) with guar phalgati (Cyamopsis tetragonoloba) and moth chara (Phaseolus aconitifolius) feeding, respectively. In another context, in Sudan, Bakheit et al. (2012) studied the effect of management systems on the growth rate of calves and reported that daily growth rate was 534 and $316 \mathrm{~g} /$ days in semi-intensive and traditional management systems, respectively.

Dabiri et al. (2003) reported that the average DWG as $700 \mathrm{~g}$ in camels aged 1-2 years in a traditional management system. In Kenya, under proper nutrition, the reported average DWG in camel calves was 870 and $570 \mathrm{~g}$ from birth to 30 days and from birth to 180 days, respectively (Wilson, 1992), while in Egypt, ElBadawi (1996) reported 830-970 g DWG from birth to 180 days in dromedary calves.

Saini et al. (2014) also reported a higher total and ADG $(\mathrm{kg})$ in stall-fed pre-pubescent camels as compared to the grazing group. In Sudan, Mohamedain et al. (2015) studied the growth performance in dromedary camels under two feeding regimens. First was the zero browsing group (15 Darfuri and 10 Butana) fed complete ration (sorghum 50\%, groundnut cake 15\%, wheat bran $5 \%$, molasses $10 \%$, dura husk $5 \%$, bagasse $12 \%$, urea $2 \%$, and common salt $1 \%$ ) to provide metabolizable energy (ME) at the rate of $11 \mathrm{MJ} / \mathrm{kg}$ dry matter (DM) and $16 \%$ crude protein (CP). Second was the free browsing group with same breeds without any supplement. The trial was for 120 days with 2 weeks as adaptation period. The average total weight gain was almost double in the zero browsing group (96 \pm $17.3 \mathrm{~kg})$ than in the free browsing group $(42 \pm 19.5$ $\mathrm{kg}$ ). ADG was $800 \mathrm{~g}$ in the zero browsing group as compared to $350 \mathrm{~g}$ in the free browsing group, while in present study, a lower DWG was observed in IMS due to the limited supply of concentrate.

Faraz et al. (2018), comparing the IMS with the SIMS regarding growth rate of camel calves, found a higher growth rate in male calves under IMS than SIMS. The values of the present study are very close to other study reported in which higher growth rates were achieved in EMS than SIMS (Faraz et al., 2017). The current findings are also in agreement with our former study (Faraz et al., 2019b) in which we compared the growth performance and hair mineral status of Marecha calves in different management systems and found a significant increase in the ADG of male and female calves being higher in IMS than SIMS. Faraz et al. (2020) compared the growth rate of weaned growing camel calves of almost 1 year of age reared under an open grazing/browsing and stall-fed system and found that the average DWG as 480 and $520 \mathrm{~g} /$ days $(p<0.05)$, respectively, under open grazing and stall-fed system, while feed conversion index (quantity of fodder $/ \mathrm{kg}$ of gain) was found to be 14.42 in stall-fed animals. The values of DWG $(\mathrm{g})$ and feed conversion index $(\mathrm{g} /$ $\mathrm{kg}$ average daily intake) of male and female weaned dromedary calves around 1 year of age were found to be $670,97.1 \mathrm{~g} ; 650,101.5 \mathrm{~g}$, and $540,154.3 \mathrm{~g} ; 440$, $125.7 \mathrm{~g}$ reared under intensive and extensive feeding management systems, respectively (Faraz, 2020b).

\section{Feed intake}

In the study of Bhakat et al. (2008), regarding the effect of management systems on growth performance of Indian camel calves, it was reported that the crop residue intake significantly varied between two groups, 5.53 versus $4.37 \mathrm{~kg} / \mathrm{calf} /$ days in ISM and SISM, respectively. Moreover, Saini et al. (2014) reported a higher DMI (kg/day) in stall-fed pre-pubescent camels as compared to the grazing group.

In the study of Bhakat et al. (2009), who determined the growth characteristics of Indian camel calves under IMS and SIMS, a non-significant intake was found by using Guar phalgati chara (C. tetragonoloba) (6.02 vs. $5.14 \mathrm{~kg} /$ calf/days), but a significance was found with moth chara (P. aconitifolius) $(7.91$ vs. $6.24 \mathrm{~kg} /$ calf/days), respectively. Furthermore, in the study of Tandon et al. (1993), dry fodder and water intake positively correlated with the growth of weaned calves. Moreover, DMI was also found to be positively correlated in Indian camel calves (Singh et al., 2000).

The findings of the present study confirmed the values reported by Faraz et al. (2019b) who compared the IMS with SIMS and found a higher crop residues intake in male and female calves under IMS than SIMS. In another study, Faraz et al. (2017) compared 
the growth performance of dromedary calves reared under EMS and SIMS and found a higher feed intake in EMS than SIMS. Such differences in feed intake could be due to the higher part of cellulose in the grazing diet. It is linked also to the time spent for grazing. In all intensive systems, animals in closed pens do not spend time for grazing, hence no energy loss for walking, and consequently their feeding capacity increases.

\section{Wool mineral status}

Determination of mineral hair composition could be an indirect tool for assessing the general health status of the animal as it is an accumulative mineral nutrition witness. The observed differences reflect better mineral nutrition in the intensive system compared to the other. To our knowledge, no work has been reported on wool mineral analysis of camel calves in Pakistan as yet. Faraz et al. (2019b) studied the growth performance and hair mineral status of Marecha camel calves in different management systems and reported a higher weight gain and mineral concentrations in calves in IMS than SIMS.

Bhakat et al. (2009) in India determined the hair mineral status of camel calves reared under different management systems and reported higher concentrations of macrominerals and microminerals in calves in SIMS. They reported calcium as $549.6 \pm 74.5$, $434.4 \pm 60.2 \mathrm{mg} / \mathrm{dl}$ and $719.7 \pm 78.6,476.0 \pm 128.0$ $\mathrm{mg} / \mathrm{dl}$, magnesium as $88.9 \pm 2.4,67.6 \pm 6.3 \mathrm{mg} / \mathrm{dl}$ and $77.5 \pm 3.7,69.8 \pm 3.2 \mathrm{mg} / \mathrm{dl}$, copper as $6.7 \pm 0.7,4.3 \pm$ $0.4 \mathrm{mg} / \mathrm{dl}$ and $7.4 \pm 0.7,5.7 \pm 1.0 \mathrm{mg} / \mathrm{dl}$, zinc as 66.0 $\pm 4.4,57.6 \pm 2.3 \mathrm{mg} / \mathrm{dl}$ and $64.3 \pm 2.0,54.8 \pm 1.5 \mathrm{mg} /$ $\mathrm{dl}$, iron as $285.7 \pm 26.6,216.0 \pm 30.9 \mathrm{mg} / \mathrm{dl}$ and 319.4 $\pm 27.9,261.9 \pm 33.4 \mathrm{mg} / \mathrm{dl}$, and manganese as $21.6 \pm$ $3.7,20.6 \pm 1.0$, and $45.8 \pm 1.8 \mathrm{mg} / \mathrm{dl}, 32.9 \pm 4.4 \mathrm{mg} /$ $\mathrm{dl}$ in calves reared under semi-intensive and IMS with guar phalgati $(C$. tetragonoloba) and moth chara $(P$. aconitifolius) feeding, respectively.

Moreover, the relationship between physical, chemical, and industrial characteristics of different dromedary camel's hair types was studied by Helal (2015), who reported higher concentrations of $\mathrm{B}, \mathrm{Cd}, \mathrm{Co}, \mathrm{Cr}, \mathrm{Fe}, \mathrm{Mn}$, $\mathrm{Ni}$, and $\mathrm{S}$ in fine hairs of Maghrebi camels, while Mo, $\mathrm{Pb}$, and $\mathrm{Zn}$ were higher in coarse fibers. Furthermore, similar studies carried out on horses (Or et al., 2004) and yaks (Chatterjee et al., 2005) revealed that the level of some mineral elements was affected by nutritional differences in horses and yaks, respectively.

\section{Conclusion}

The current research findings confirmed higher gains in male calves in IMS. It is of the opinion that Pakistani camel calves have greater production potential that could be exploited by modern husbandry techniques on scientific lines. Definitely, it will be a useful addition to the food chain. Male calves should be utilized for meat production, while the higher growth rate of females should be utilized to achieve a more precocious reproduction age for heifers. Constituents entering into the body are accumulated in hairs and also reflect the nutritional status of the animal. These levels could be used in the diagnosis of various diseases and metabolic disorders of the animal. This article describes the growth rate and hair mineral status of young calves reared under two management systems in desert conditions and could be used as a primary database for future studies in this field.

\section{Significance of the study}

The role of camels in the economy of marginal areas of the world and society is well documented, but it is still one of the most ignored species in Pakistan. Being a valuable genetic resource, initiatives have been taken to illustrate production potential and related parameters of camels under natural milieus. Previous studies did not validate penetrating requirements of the subject; hence extensive studies of Pakistani camels under different management systems are desired. The current study covers the growth parameters and hair mineral analysis of camel calves reared in IMS and EMS and provides comprehensive material about these parameters lacking in previous studies. This study will not only condense the thirst of the scientific community by plotting footprints to develop a database for camel production and reproduction but it will also go a long way to reconnoiter novel and unmapped areas of camel production to provide solid recommendations for the camel farming community.

\section{Acknowledgements}

The authors gratefully acknowledge the cooperation and kind support of the management of the CBRS, Rakh Mahni, District Bhakkar, Punjab, Pakistan. The financial support of the Higher Education Commission Islamabad, Pakistan, made this study possible.

\section{Conflict of interest}

The authors declare that there is no conflict of interest. Authors' Contributions

All authors contributed to make the completion of this manuscript possible. AF conducted the research and wrote the article; AW helped in the analysis, NAT and $\mathrm{ABM}$ helped in writing the article, and AOA helped in analyzing and reviewing the article.

\section{References}

AOAC. 1990. Official methods of analysis of the association of official analytical chemists. Washington, DC: AOAC.

Bakheit, S.A., Idris, A., Faye, B. and Abdelhadi, O. The effect of management system on camel's milk yield and calve growth rate in North Kordofan, Sudan. In Conference International Research on Food Security, Natural Resource Management and Rural Development, 2012 Sept 19-21, Gottingen, Germany.

Bhakat, C., Saini, N. and Pathak, K.M.L. 2008. Effect of management systems on the performance of dromedary camel calves reared under organized farm condition. Indian J. Anim. Sci. 78, 1023-1027. 
Bhakat, C., Saini, N. and Pathak, K.M.L. 2009. Growth characteristics, economics and hair mineral status of camel calves reared in different systems of management. Indian J. Anim. Sci. 79, 932-935.

Chatterjee, A., Raquib, M., Sheikh, I.U. and Bhattacharya, M. 2005. Elemental status in Yak hair. Indian Vet. J. 82, 526-528.

Dabiri, N.G., Faiazi, J. and Shadmanesh, A. 2003. Effect of different levels of energy and protein on fattening performance of camels. Iranian J. Agri. Sci. 34, 169-176.

El-Badawi, A.Y. The possibilities of using camels in new reclaimed lands. In Proceedings The first meeting of the National Committee for Camel Research in the Arab Republic of Egypt, 1996 Nov 16, Cairo, Egypt.

FAOSTAT. 2019. FAO statistics division. Rome, Italy: FAOSTAT.

Faraz, A. 2020a. Portrayal of Camelid production in desert ecosystem of Pakistan. J. Zool. Res. 2(3): 15-20.

Faraz, A. 2020b. Growth potential of Camelus dromedarius calves reared under intensive and extensive feeding management systems. Pakistan J. Zool. 52, 1493-1500.

Faraz, A., Waheed, A., Mirza, R.H. and Ishaq, H.M. 2019a. Role of camel in food security: a perspective aspect. J. Fisheries Livest. Prod. 7, 290; doi: 10.4172/2332-2608.1000290.

Faraz, A., Waheed, A., Mirza, R.H., Ishaq, H.M. and Nabeel, M.S. 2020. Comparison of growth rate of Camelus dromedarius calves reared under open grazing/browsing and stall fed system. Pak. J. Zool. 52, 809-812.

Faraz, A., Younas, M., Lateef, M. and Muhammad, G. 2018. Effect of intensive and semi-intensive management systems on growth performance and economics of Marecha (Camelus dromedarius) calves reared under desert conditions. Pak. J. Agri. Sci. 55, 625-632.

Faraz, A., Younas, M., Lateef, M., Yaqoob, M. and Muhammad, G. 2017. Comparative growth performance of Marecha Calves (Camelus dromedarius) reared under semi-intensive and extensive management systems. J. Anim. Plant Sci. 27, 1067-1074.

Faraz, A., Younas, M., Waheed, A., Yaqoob, M. and Ishaq, K. 2019b. Growth performance and hair mineral status of Marecha (Camelus dromedarius) calves reared under different management systems. Pak. J. Zool. 51, 503-509.

Faye, B. 2016. Food security and the role of local communities in the non-cow milk production. In Non-bovine milk and milk products. Eds., Tsakalidou, E., and Papadimitriou, K. London, UK: Elsevier and AP Publ, pp: 1-13.
GOP. 2019-20. Economic advisor's wing. Islamabad, Pakistan: Ministry of Finance, Government of Pakistan Islamabad.

Helal, A. 2015. Relationships among physical, chemical and industrial characteristics of different dromedary camel's hair types. J. Am. Sci. 11, 67-75.

Hossner, K.L. 2005. Hormonal regulation of farm animal growth. Cambridge, MA: CABI Publishing.

Khanna, N.D., Rai, A.K. and Tandon, S.N. 2004. Camel breeds of India. The Camel Applied Research and Development Network (CARDN). J. Camel Sci. 1, 8-15.

Knoess, K.H. 1977. The camel as a meat and milk animal. World Anim. Rev. 22, 39-42.

Kurtu, M.Y. 2004. An assessment of the productivity for meat and carcass yield of camels (Camelus dromedarius) and of the consumption of camel meat in the eastern region of Ethiopia. Trop. Anim. Health Prod. 36, 65-76.

Mohamedain, N.M., Fadlalla, I.M.T., Barri, M.E. and Abdel-Aziz, B.E. Growth performance in dromedary camels under two feeding regimen. The Regional Conference of Camel Management and Production under Open Range System (RCCMPR), Khartoum-Sudan, 2015 Mar 2-4, 2015.

Musavaya, K. 2003. Weight development in camels of different age and sex classes under field conditions in a semi-arid area in northern Kenya. Master Thesis, available at Available via http//www.troz. uni-hohenheim.de/research/Thesis/MScAP

Mustafa, A.B., Elagba, H.A.M. and Atti, K.A.A. 2015. Impact of management systems and dam aging on growth rate of camel calve. Int. J. Adv. Pharm. Bio. Chem. 4, 1-4.

Or, M.E.K., Maden, A., Gulyasar, D., Tosun, R. and Dourka, C. 2004. Determination of trace elements $(\mathrm{Fe}, \mathrm{Cu}$ and $\mathrm{Zn}$ ) in serum and tail hair of healthy horses as a function of nutritional differences in certain months. Nigerian Vet. J. 25, 9-13.

Ouda, J.O., Mbni, M.K. and Woie, B.M. 1992. Production performance of Somali and Rendille camels and their crossbreeds in northern Kenya. Paper presented at all African Conference on Animal Agriculture, Nairobi, Kenya.

Qureshi, M.H. 1986. The camel: a paper presented at a seminar on the camel, Kuwait. Rome, Italy: FAO, pp: $1-35$.

Rahim, S.M.A., Hasnain, S. and Farkhanda, J. 2011. Effect of calcium, magnesium, sodium and potassium on farm plantations of various agroecological zones of Punjab, Pakistan. Afr. J. Plant Sci. 5, 450-459.

Sahani, M.S., Bissa, U.K. and Khanna, N.D. Factors influencing pre and post weaning body weights and daily weight gain in indigenous breeds of camels under farm conditions. Proceedings 3rd 
Annual Meeting for Animal Production under Arid Conditions. UAE University, 1998, 1, pp 59-64.

Saini, N., Kiradoo, B.D. and Bohra, D.L. 2014. Impact of feeding on growth performance, blood biochemical and mineral profiles of pre-pubescent camels under pastoral management in arid western Rajasthan. Trop. Anim. Health Prod. 46, 987-994.

Singh, G.P., Nagpal, A.K., Saini, N. and Jayant, P. 2000. Studies on feed requirement and feed resources evaluation for optimum production. Annual Report, NRCC; 26-34 pp.

SPSS, Inc. Released 2008. SPSS Statistics for Windows, Version 17.0. Chicago, IL: SPSS Inc.

Steel, R.G.D., Torrie, J.H. and Dicky, D.A. 1997. Principles and procedures of statistics. A biometric approach, 3rd Ed. New York, NY: McGraw Hill Book Co.
Tandon, S.N., Khanna, N.D. and Sharma, N., 1993. To develop suitable management practices for rearing camels. Annual Report, NRCC; 45-49 pp.

Van Soest, P.J., Robertson, J.B. and Lewis, B.A. 1991. Method for dietary fiber, neutral detergent fiber, and nonstarch polysaccharides in relation to animal nutrition. J. Dairy Sci. 74, 3583-3597.

Von Engelhardt, W., Haarmeyer, P. and LechnerDoll, M. 2006. Feed intake, forestomach fluid volume, dilution rate and mean retention of fluid in the forestomach during water deprivation and rehydration in camels (Camelus sp.). Comp. Bioch. Physiol. Part A. 143, 504-507.

Wilson, R.T. Factors affecting weight and growth in one humped camels. In Proceedings First International Camel Conference, 1992 February 2-6, Dubai, 1992, pp: 309-312. 